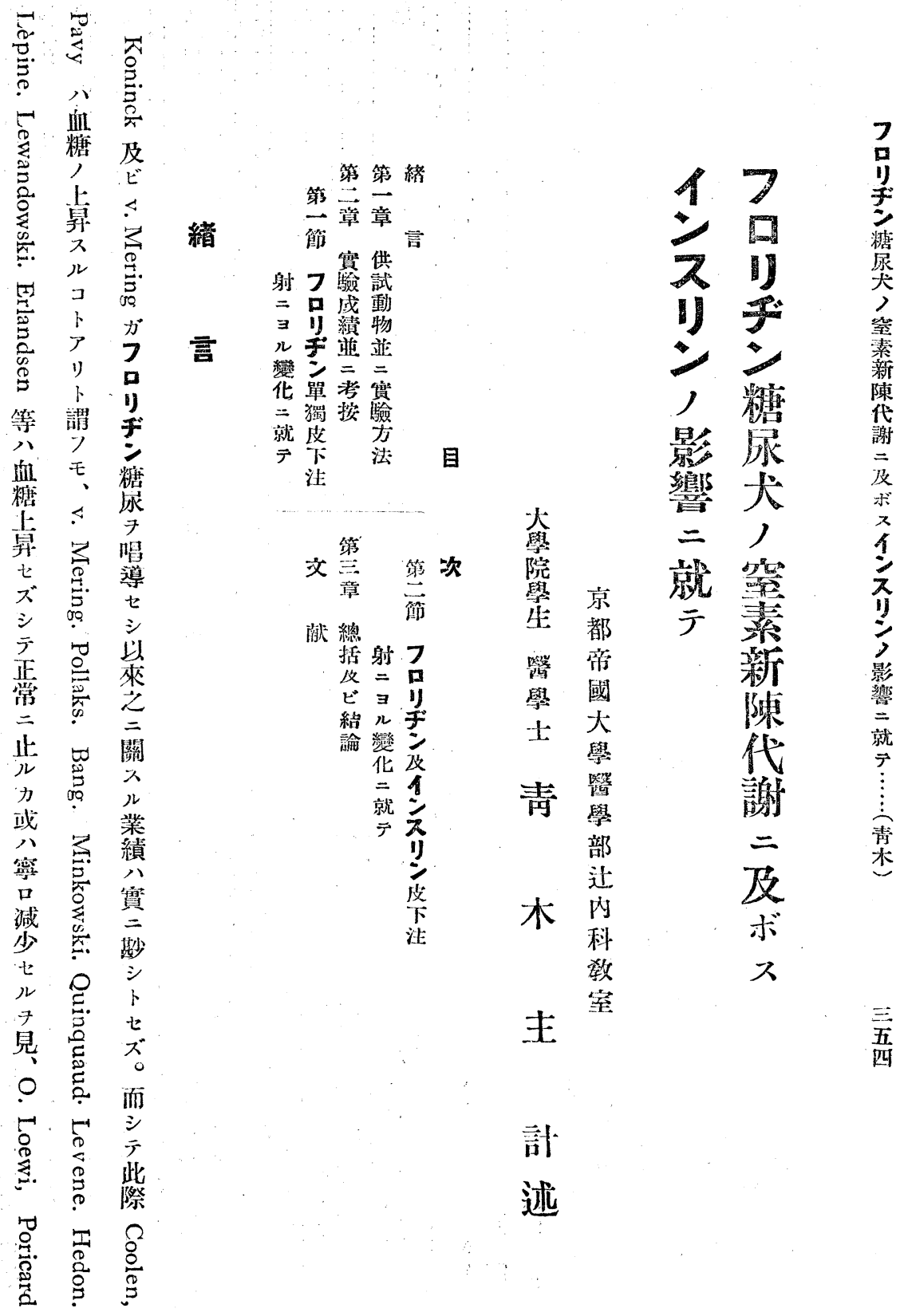




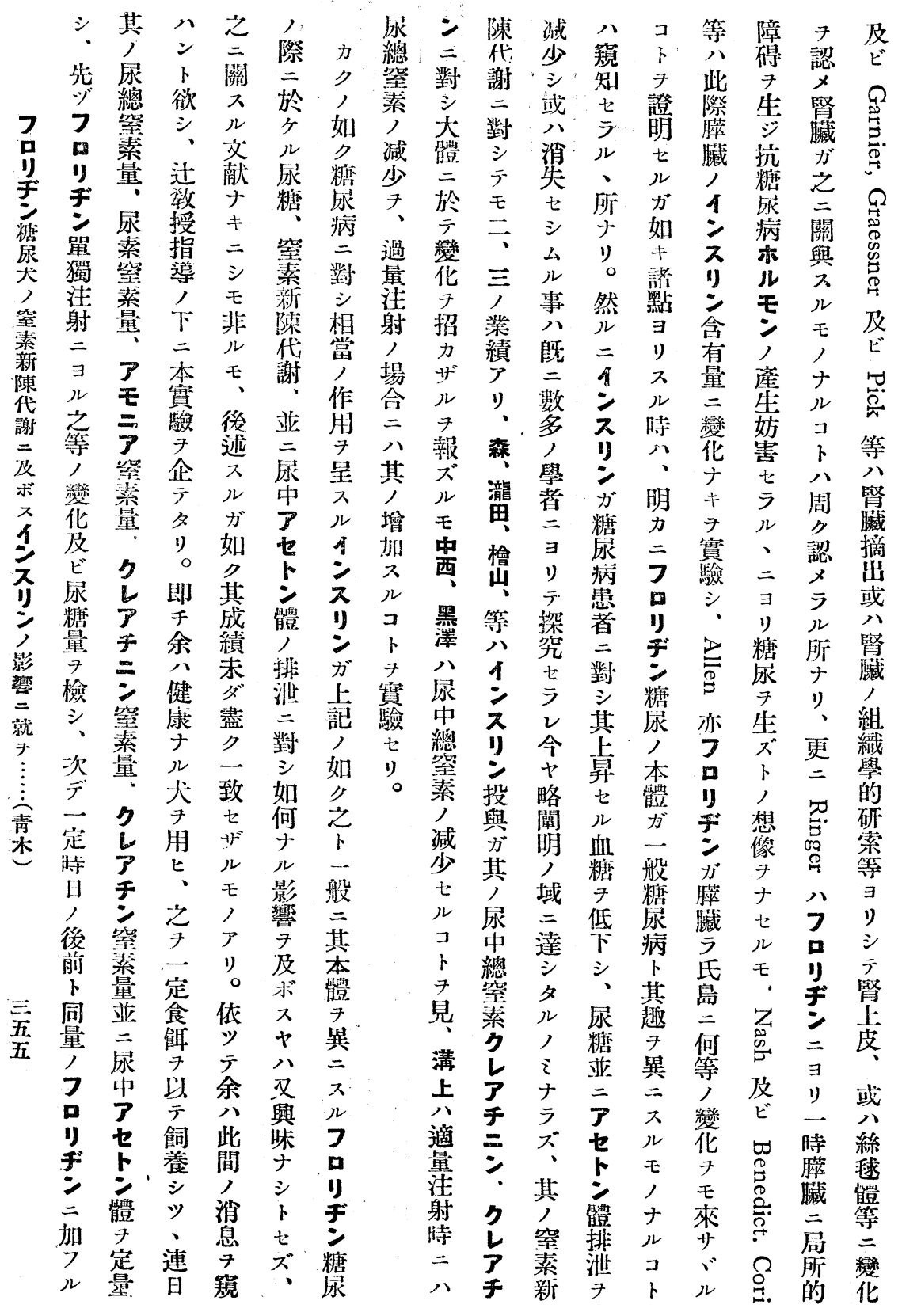




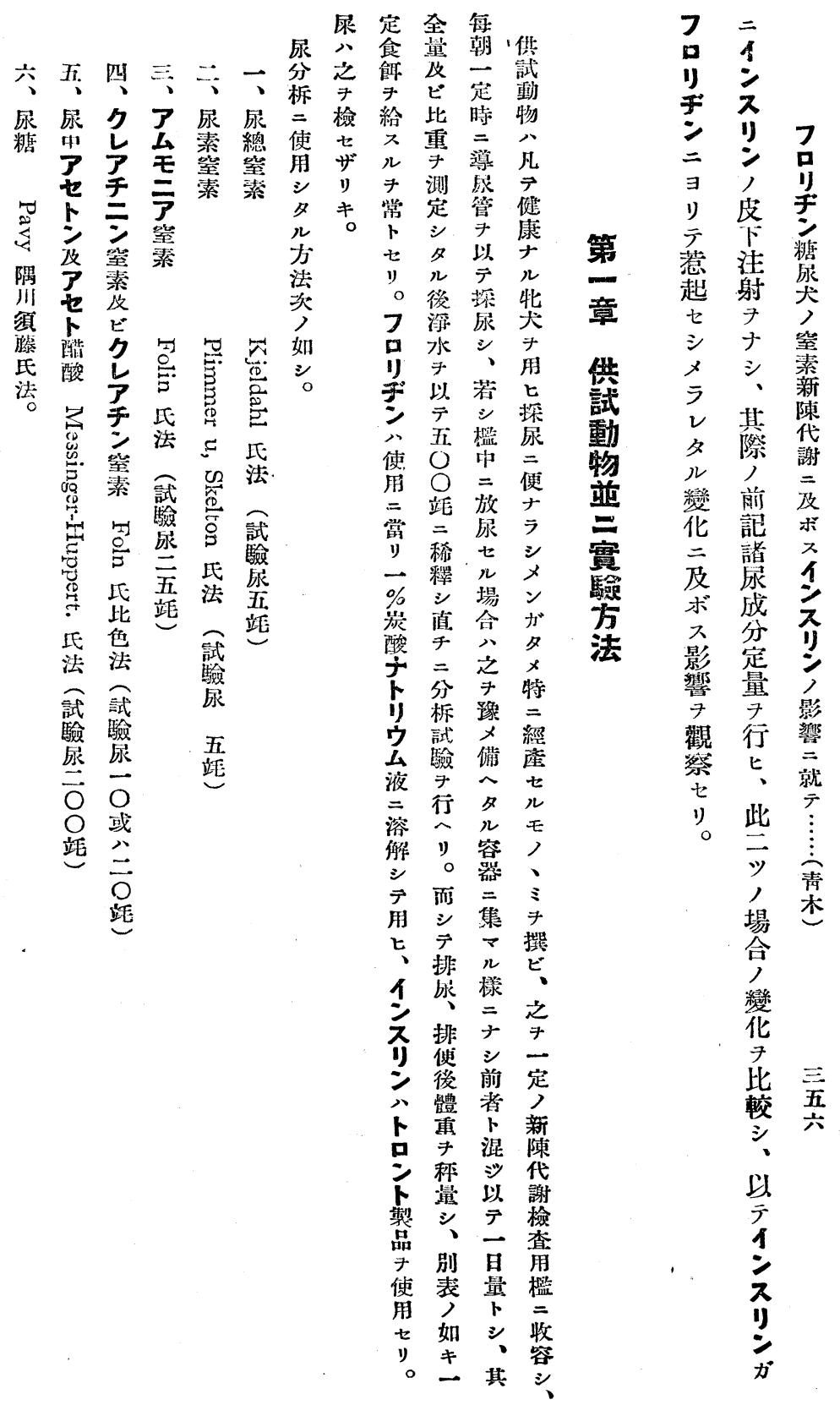




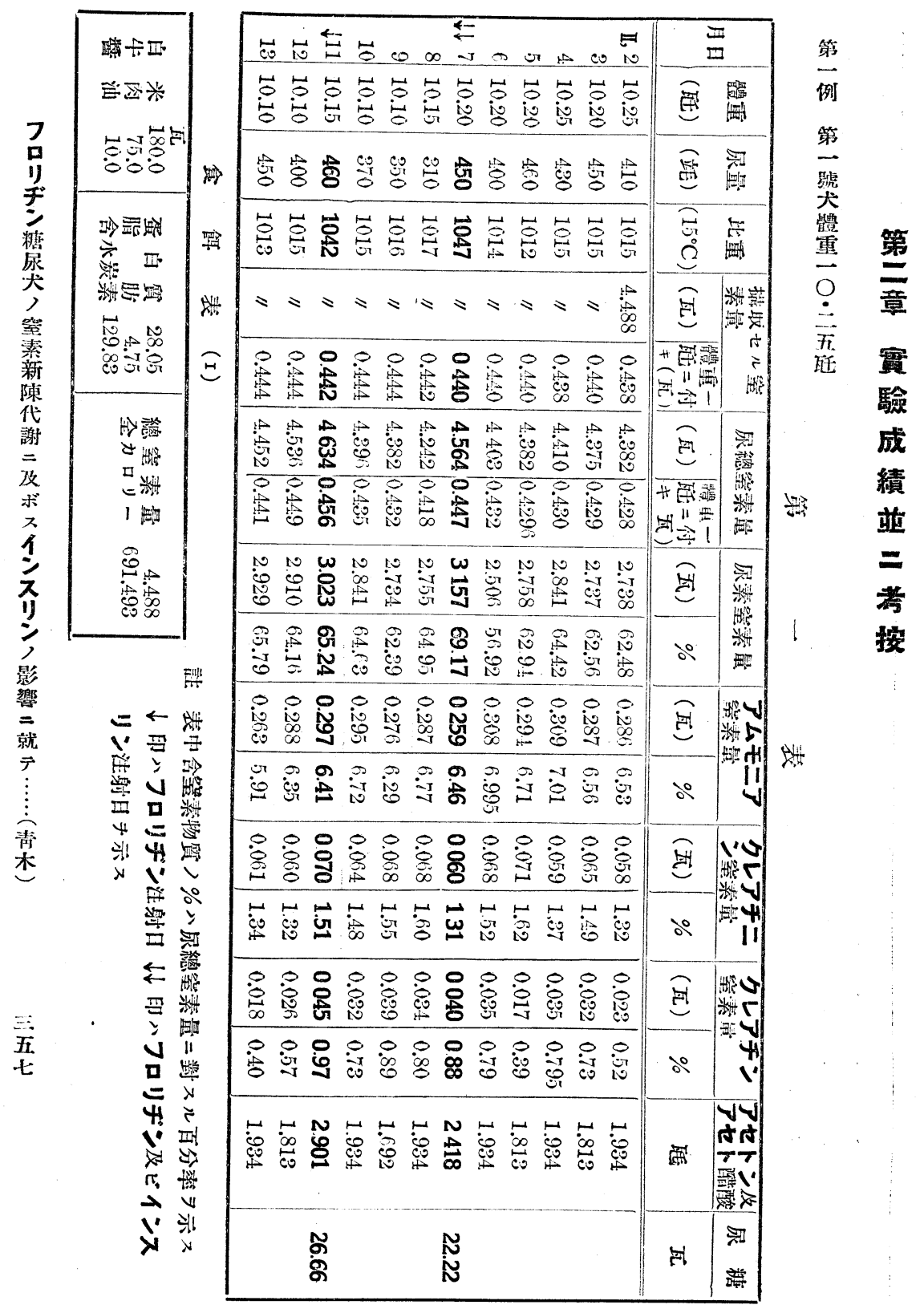




\begin{tabular}{|c|c|}
\hline 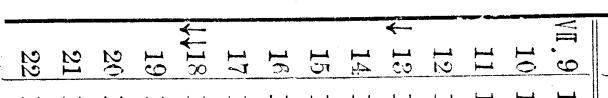 & $\stackrel{m}{=}$ \\
\hline 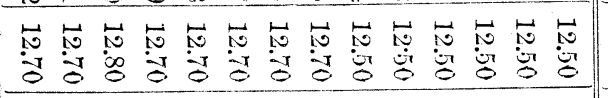 & 簬 \\
\hline 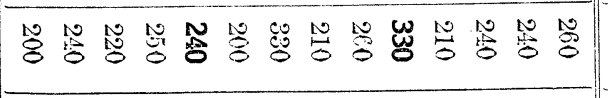 & 要羂 \\
\hline 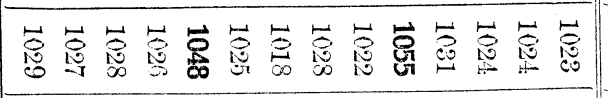 & 琴 \\
\hline 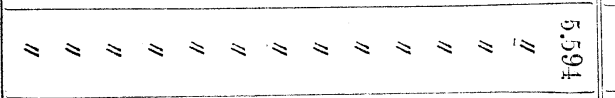 & 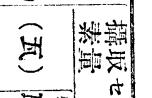 \\
\hline 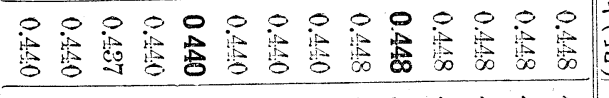 & 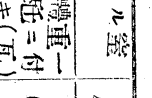 \\
\hline 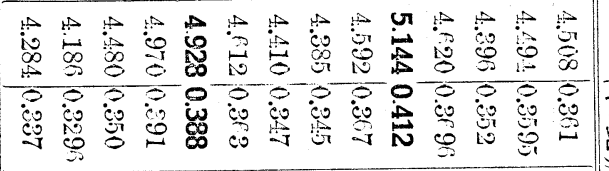 & 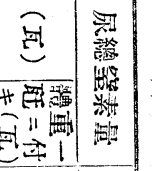 \\
\hline 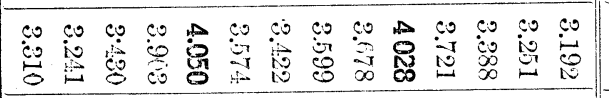 & 焉 \\
\hline 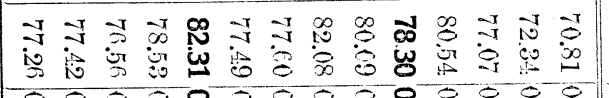 & $\therefore$ 籍 \\
\hline 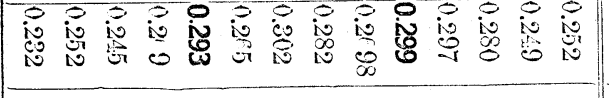 & 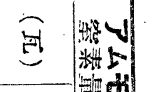 \\
\hline 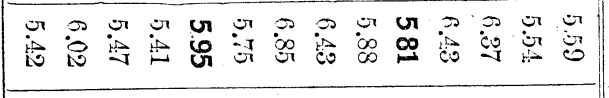 & $\therefore \quad$ \\
\hline 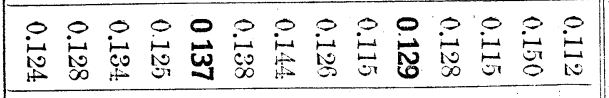 & 司| \\
\hline 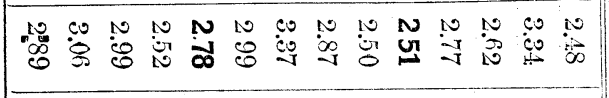 & $\therefore$ \\
\hline 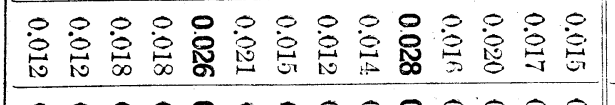 & 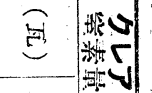 \\
\hline 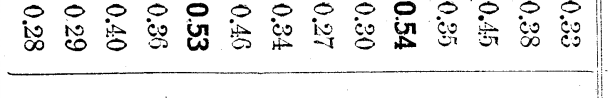 & $\left.\therefore\right|_{\pi \rightarrow \infty} ^{*}$ \\
\hline 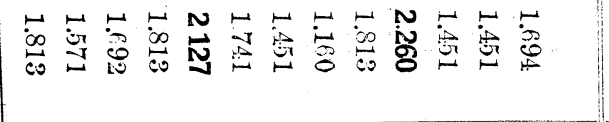 & 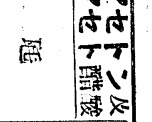 \\
\hline 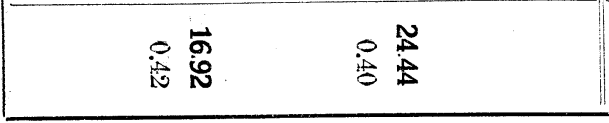 & \\
\hline
\end{tabular}

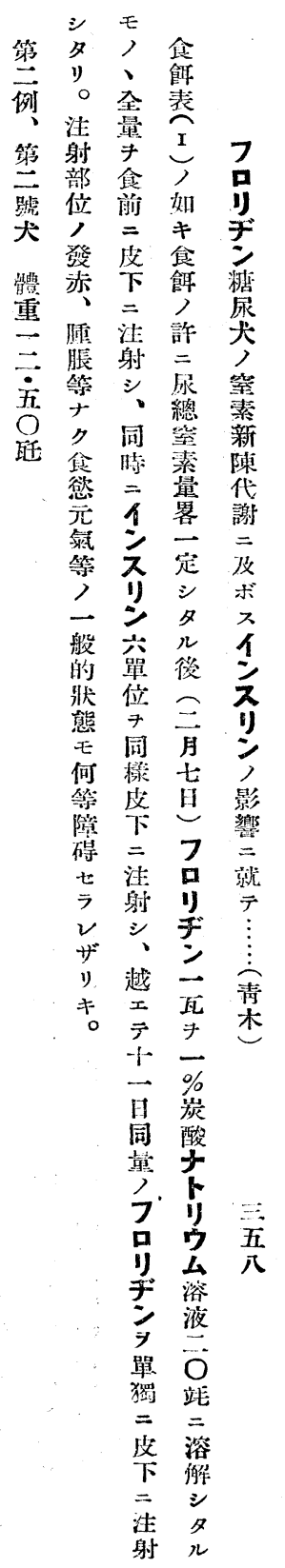




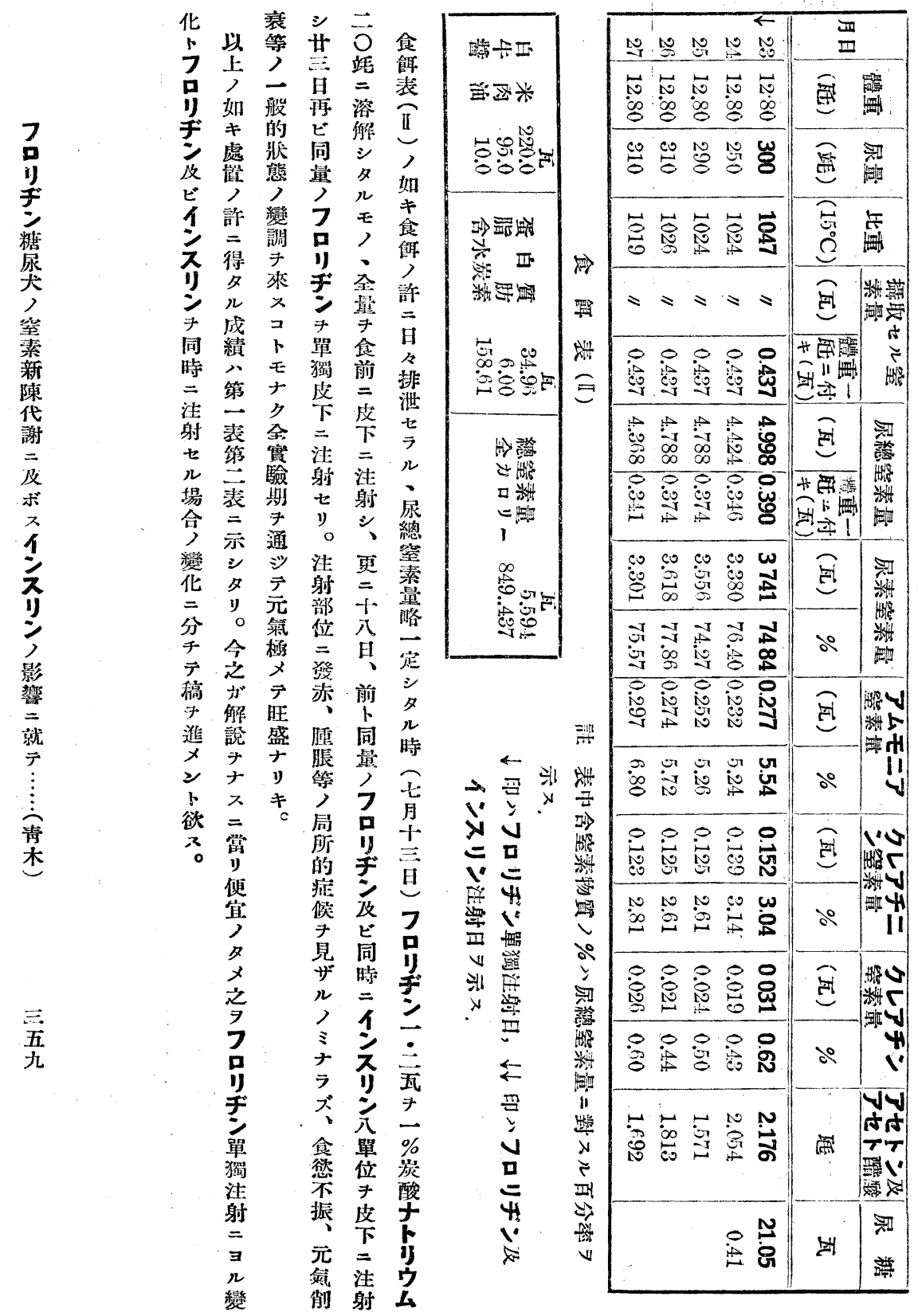




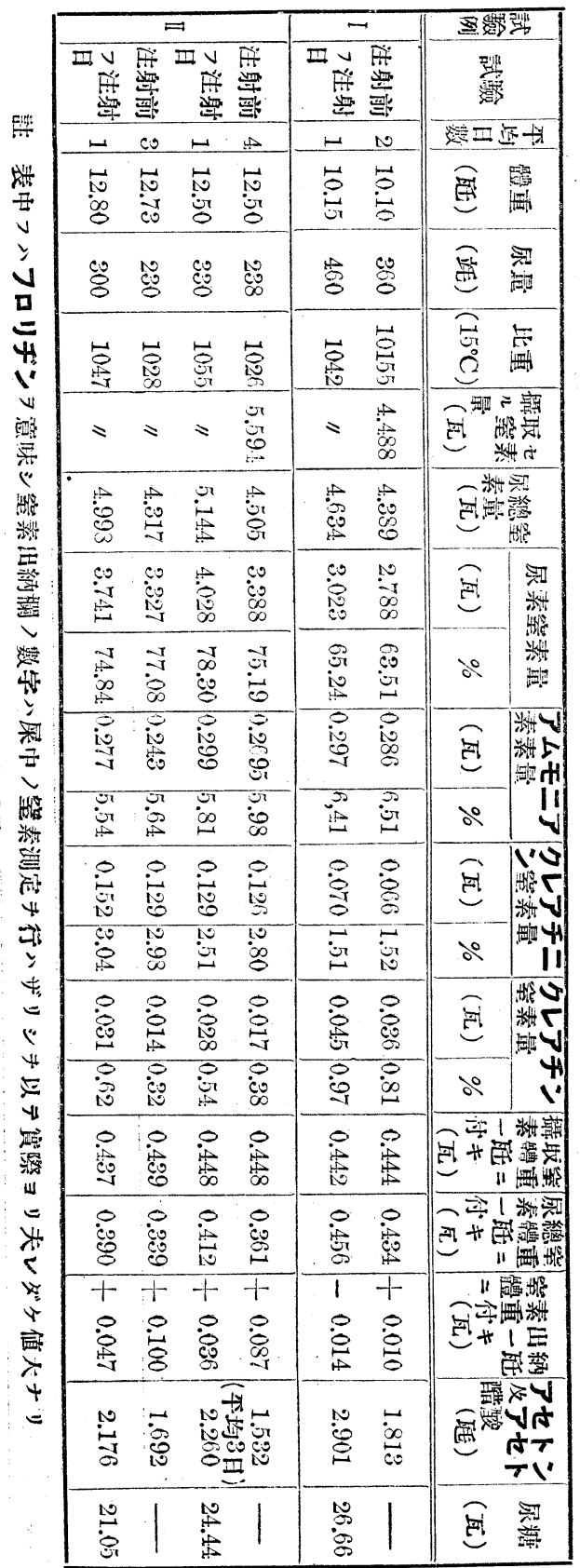

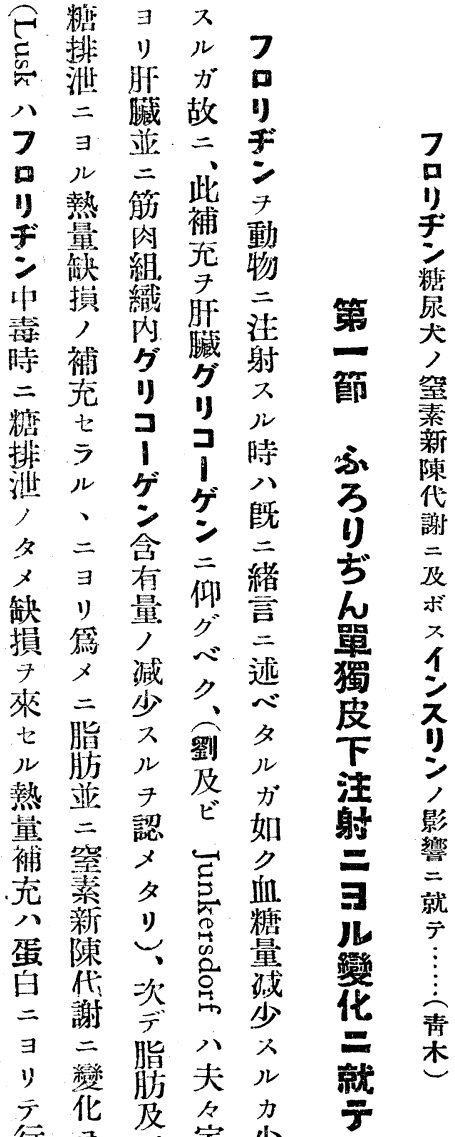

行子家少

八來蛋蒠》

人不及百莫

脂事筫犬變

肪 背三化

代想基就ナ

克得泉亏方

進 今待口尿

子 奨り中

見所力手糖

トナク注子

〉》。 


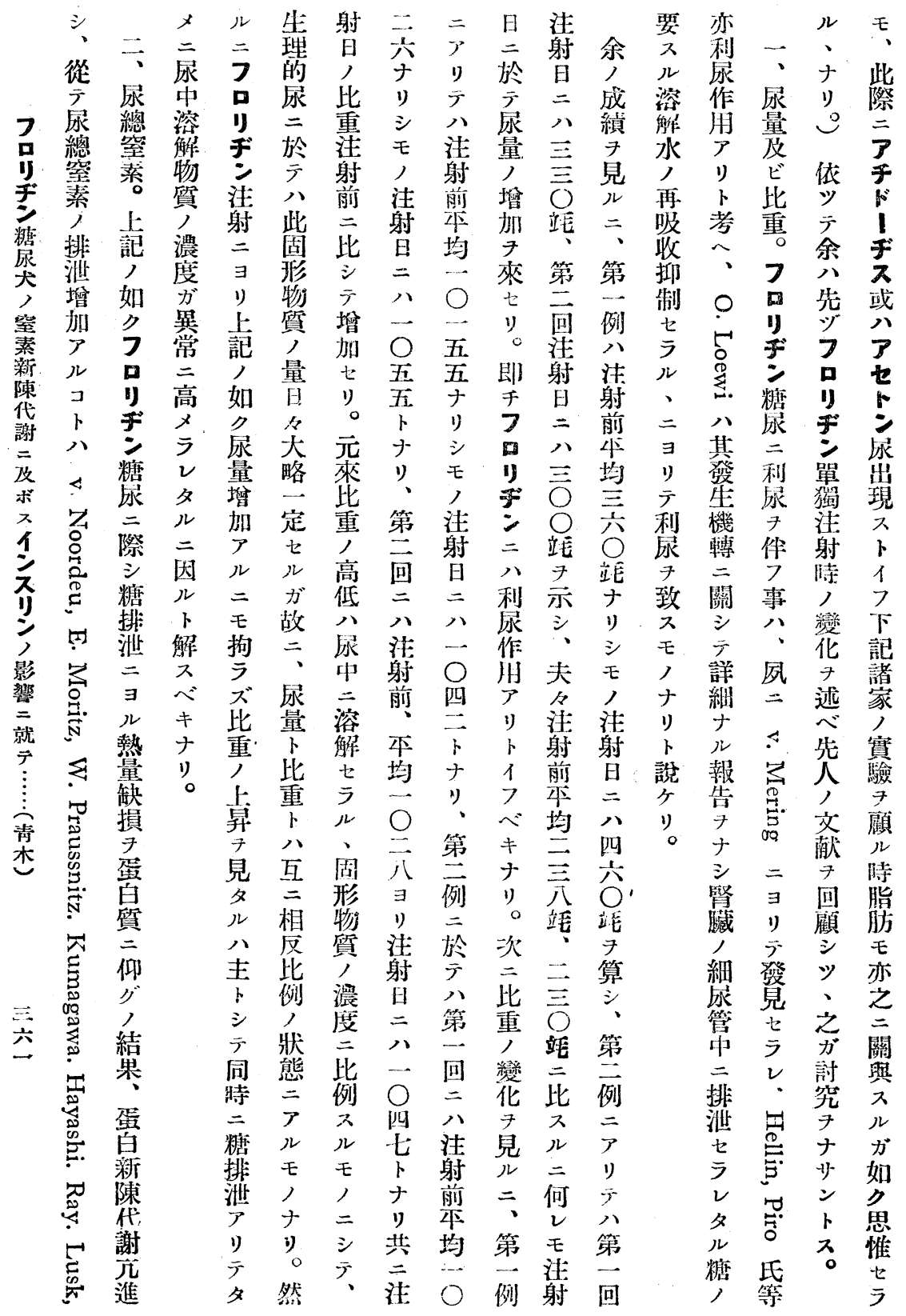




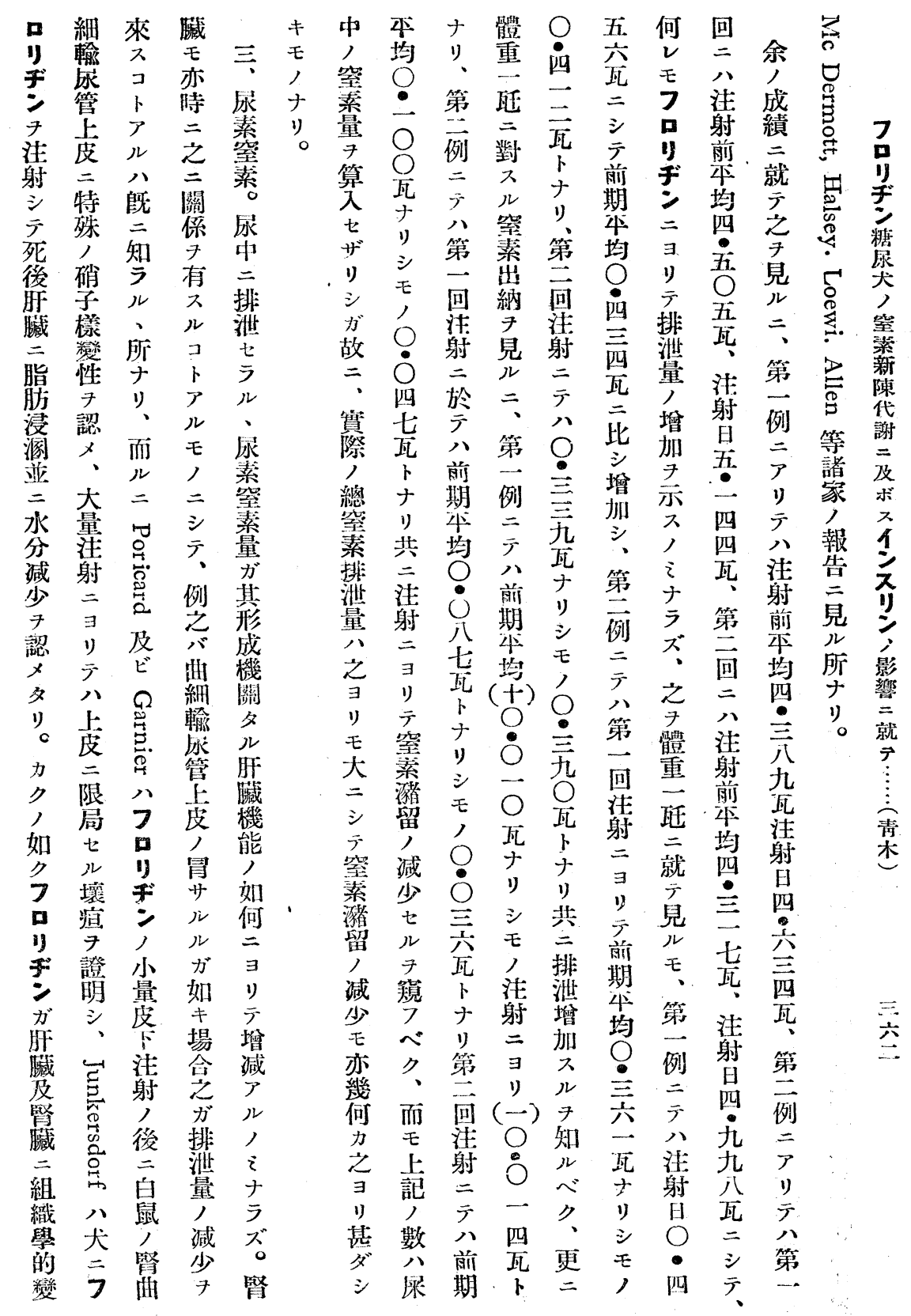




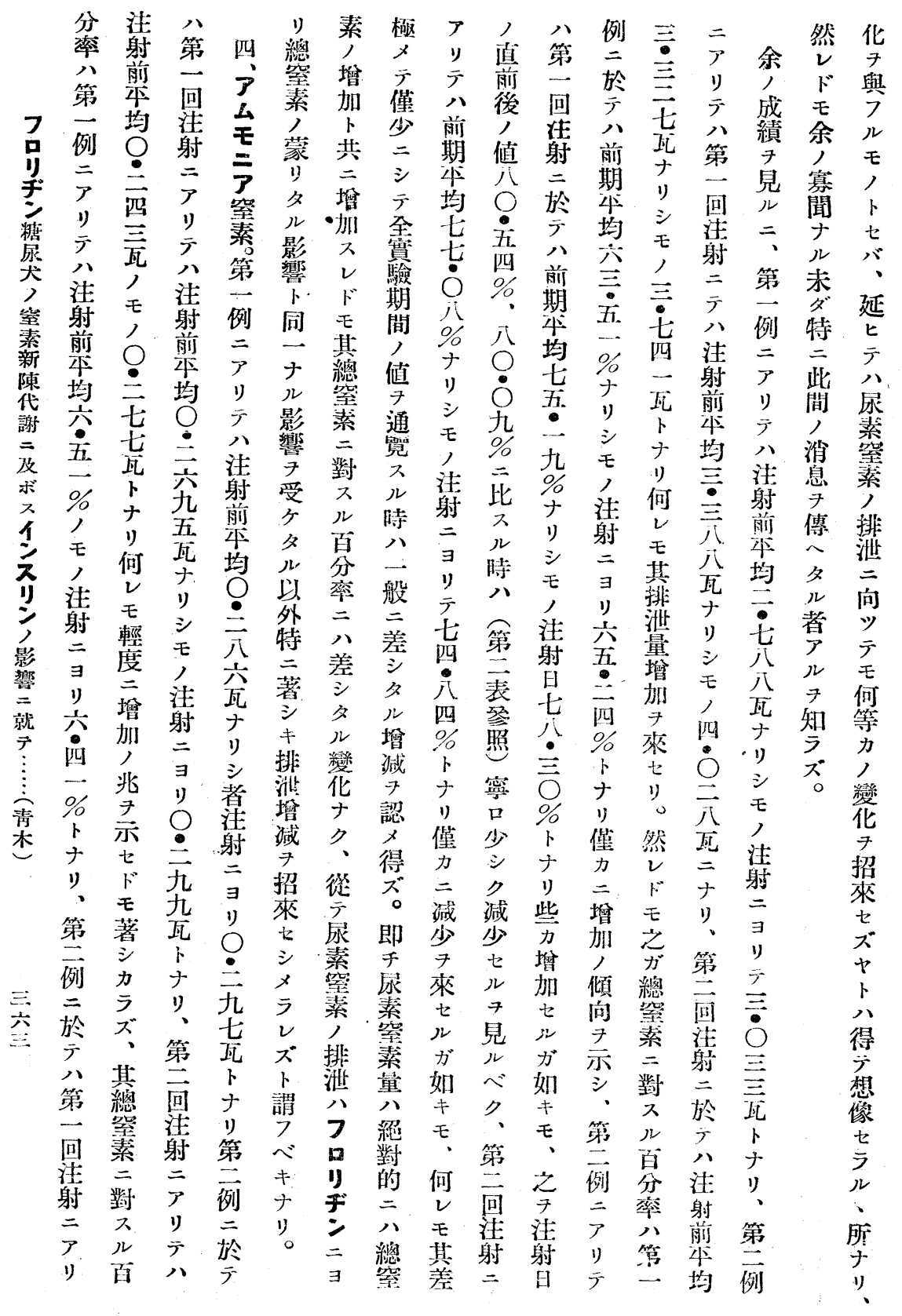




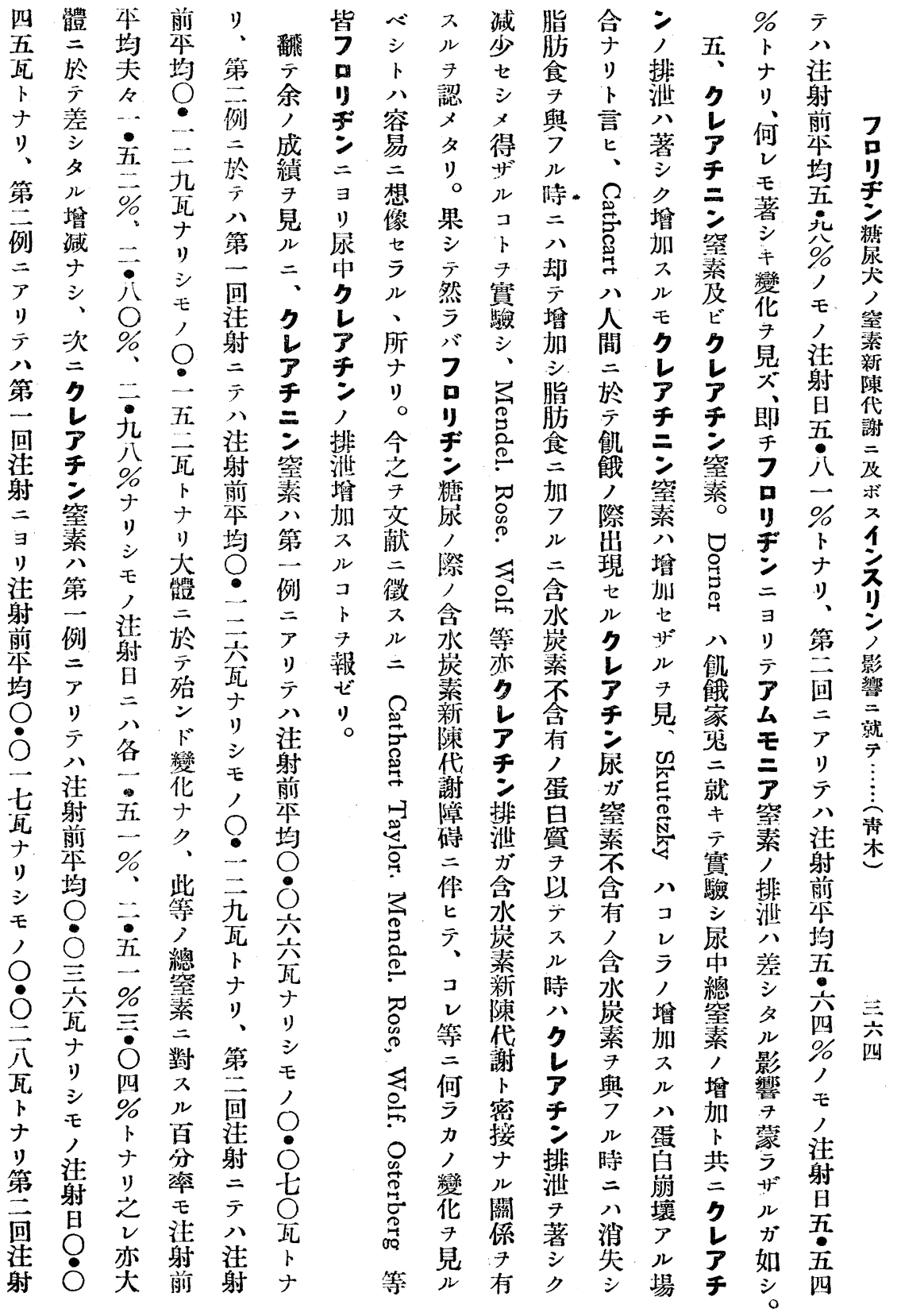




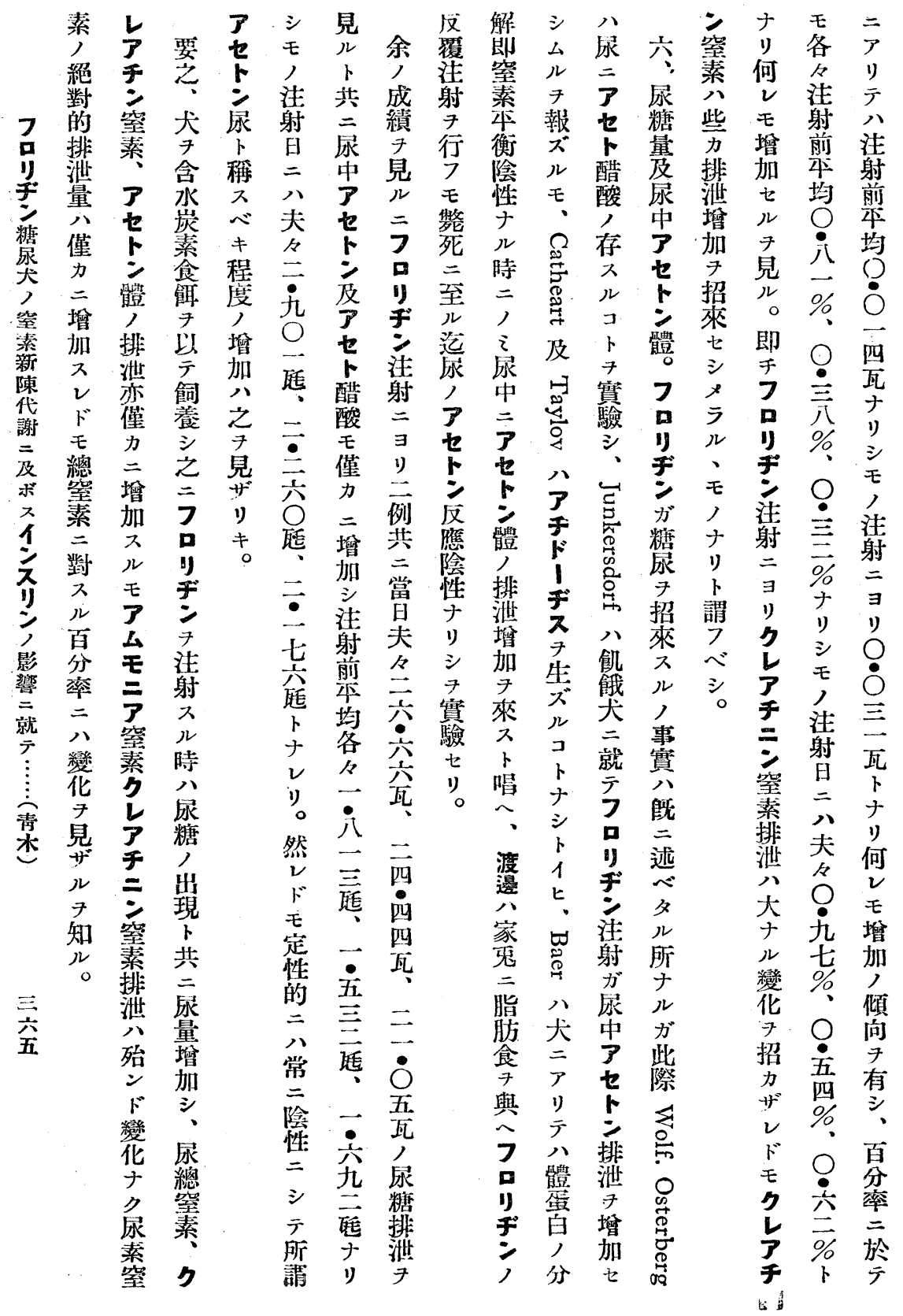




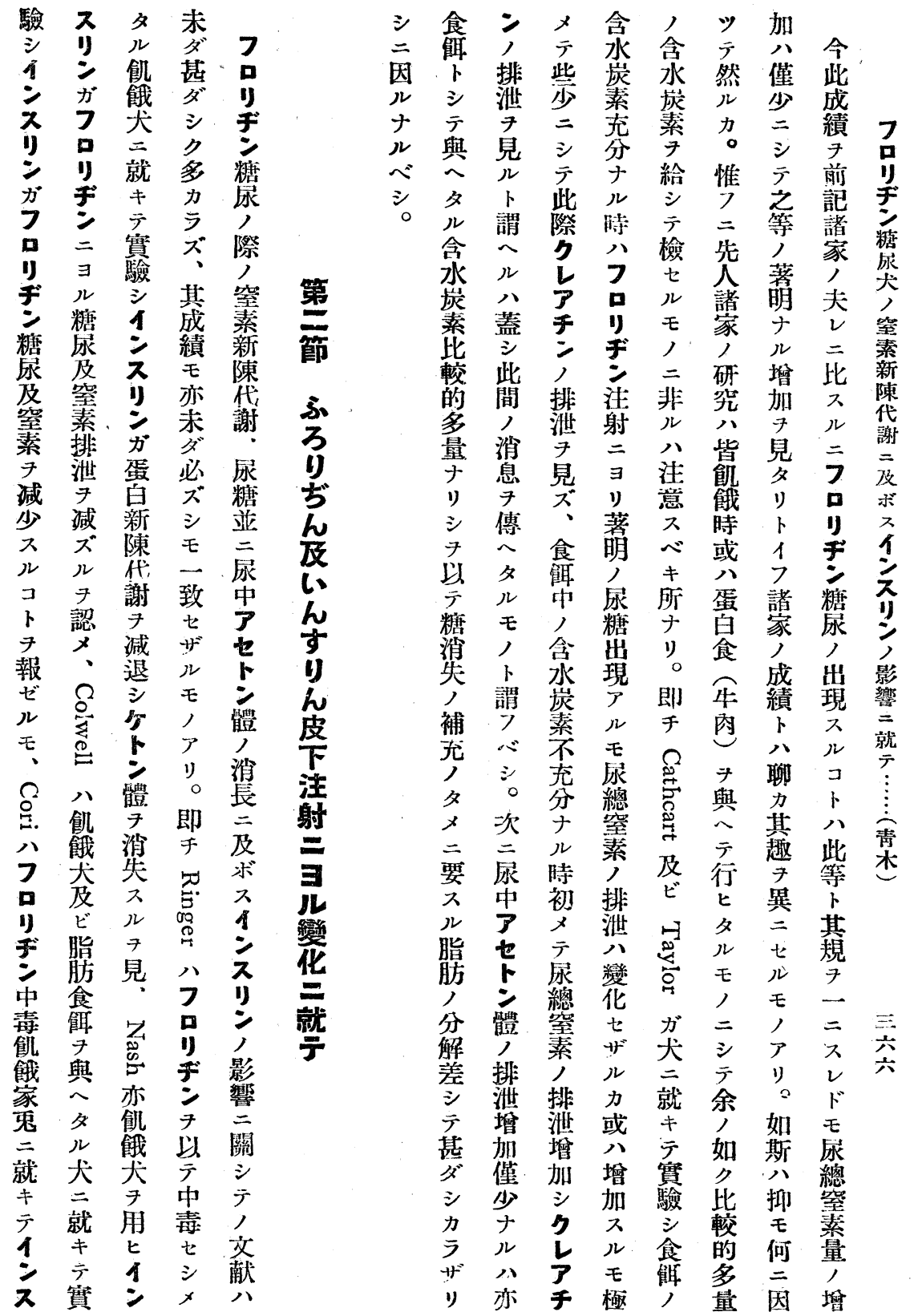




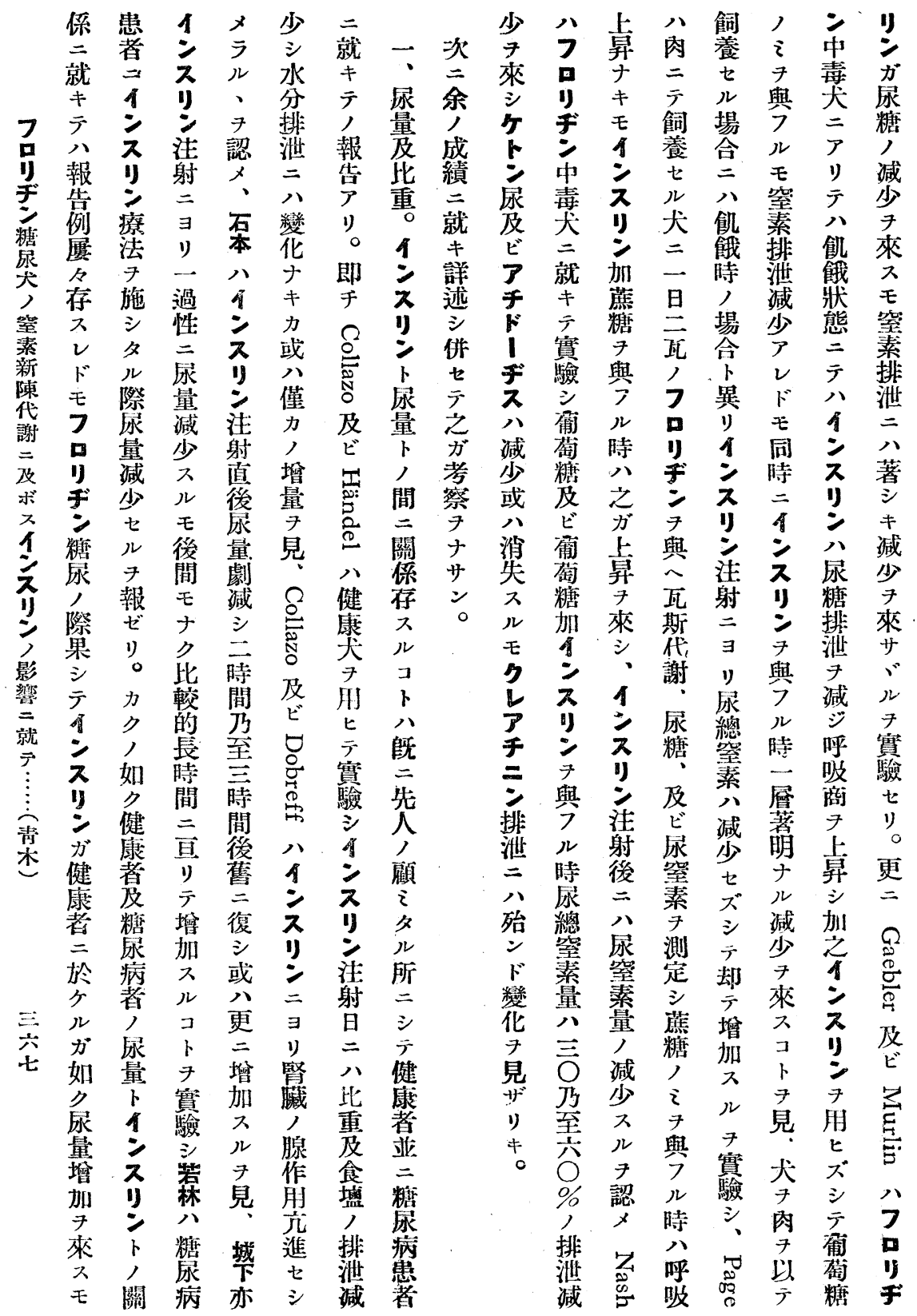




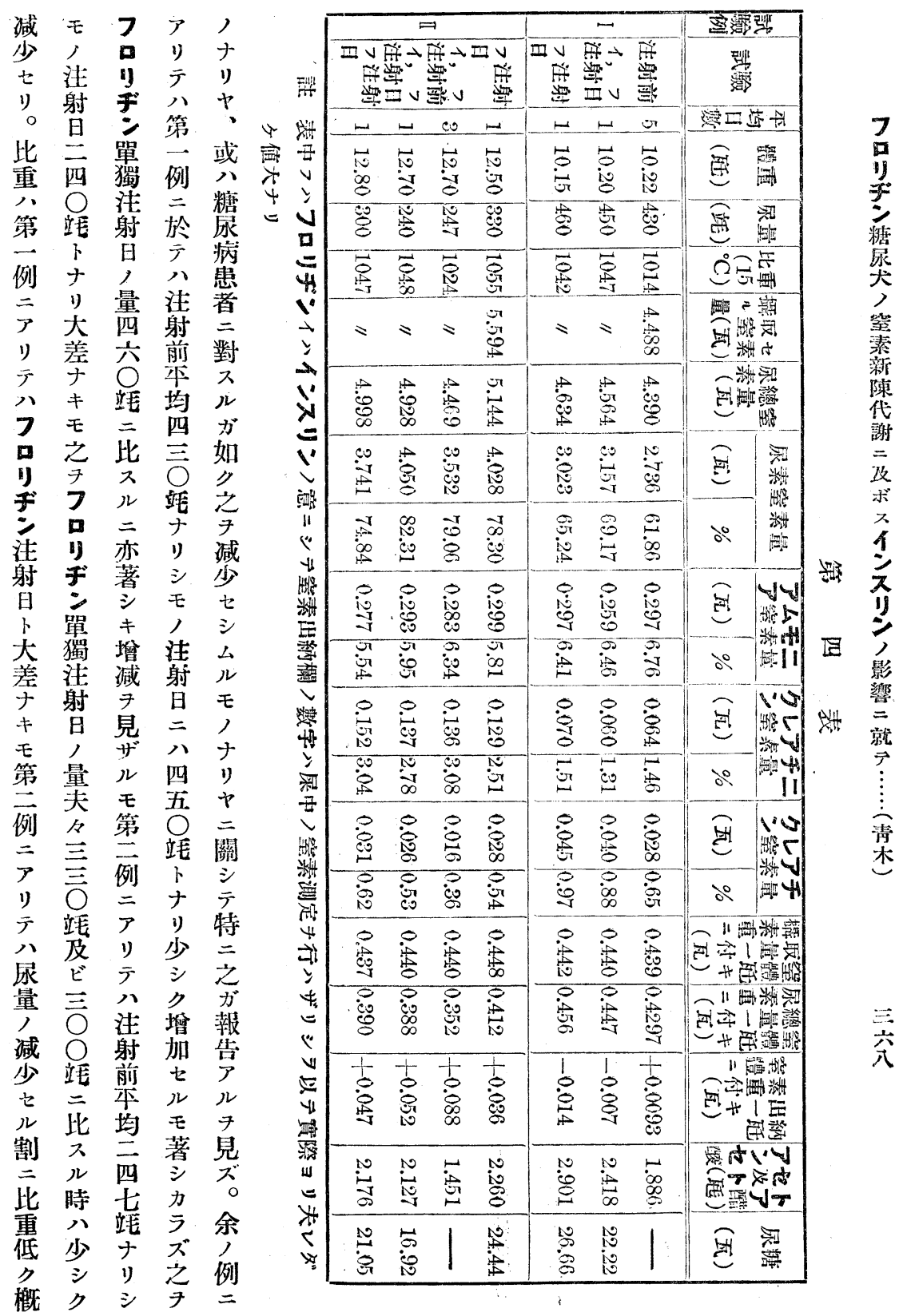




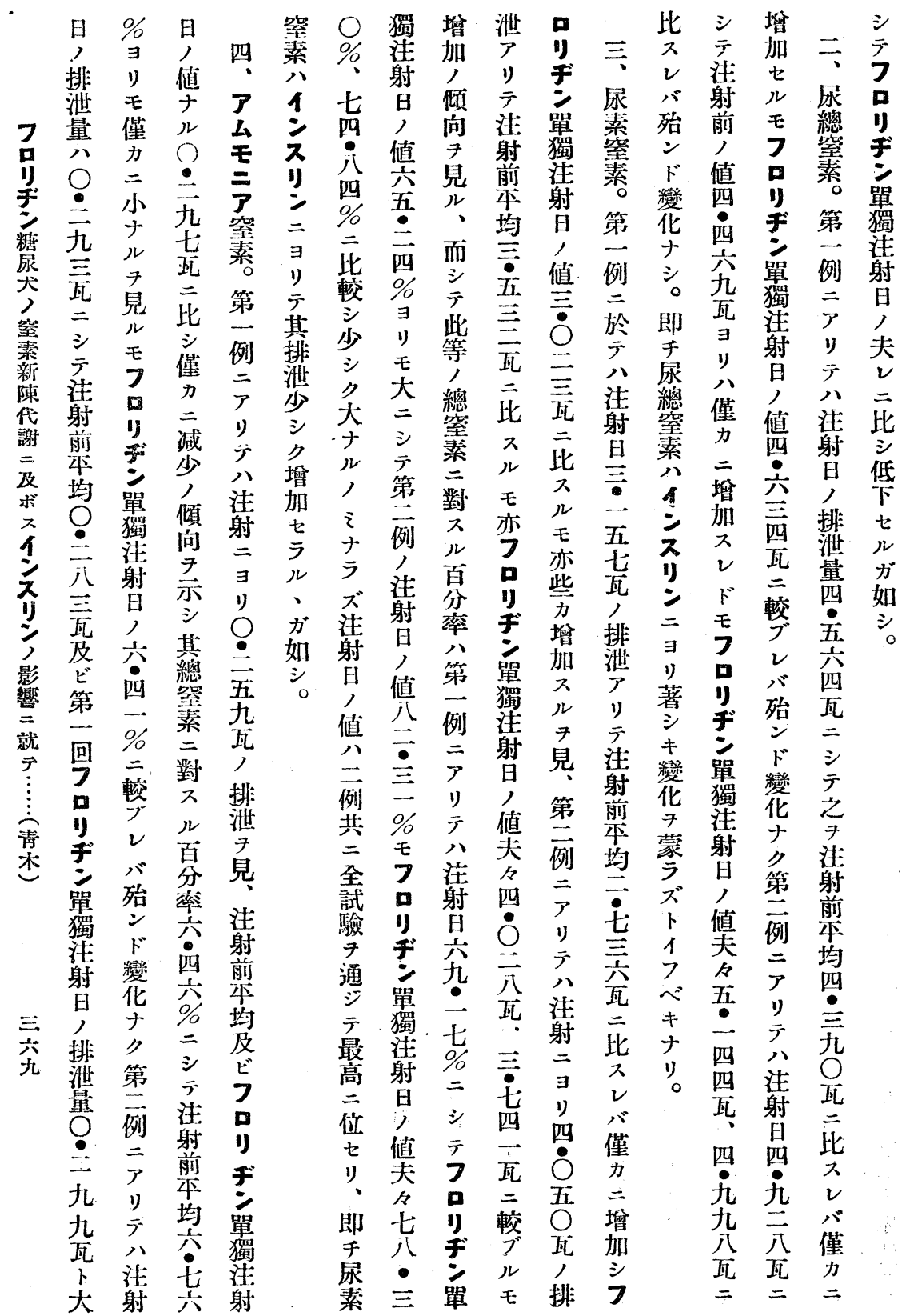




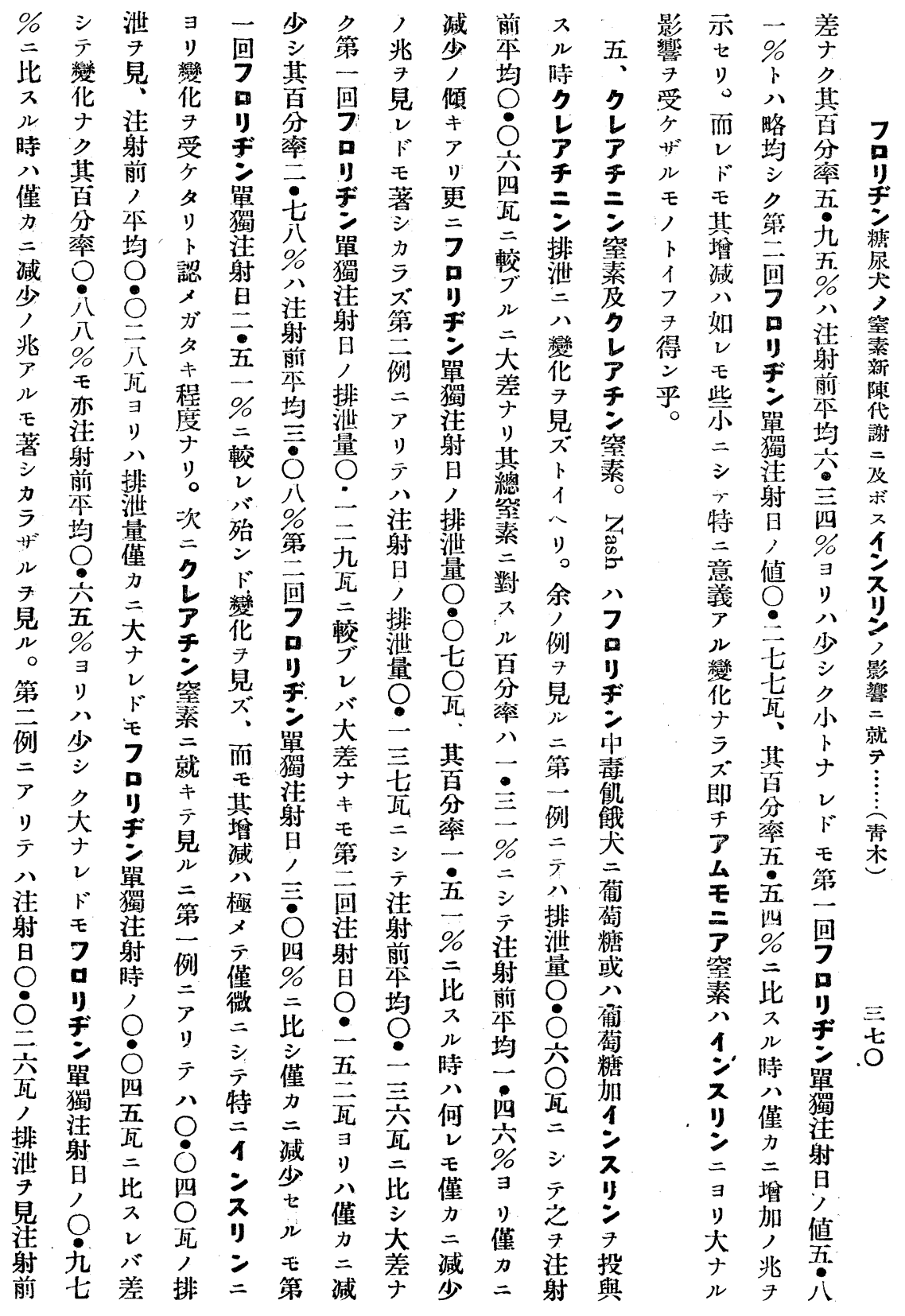




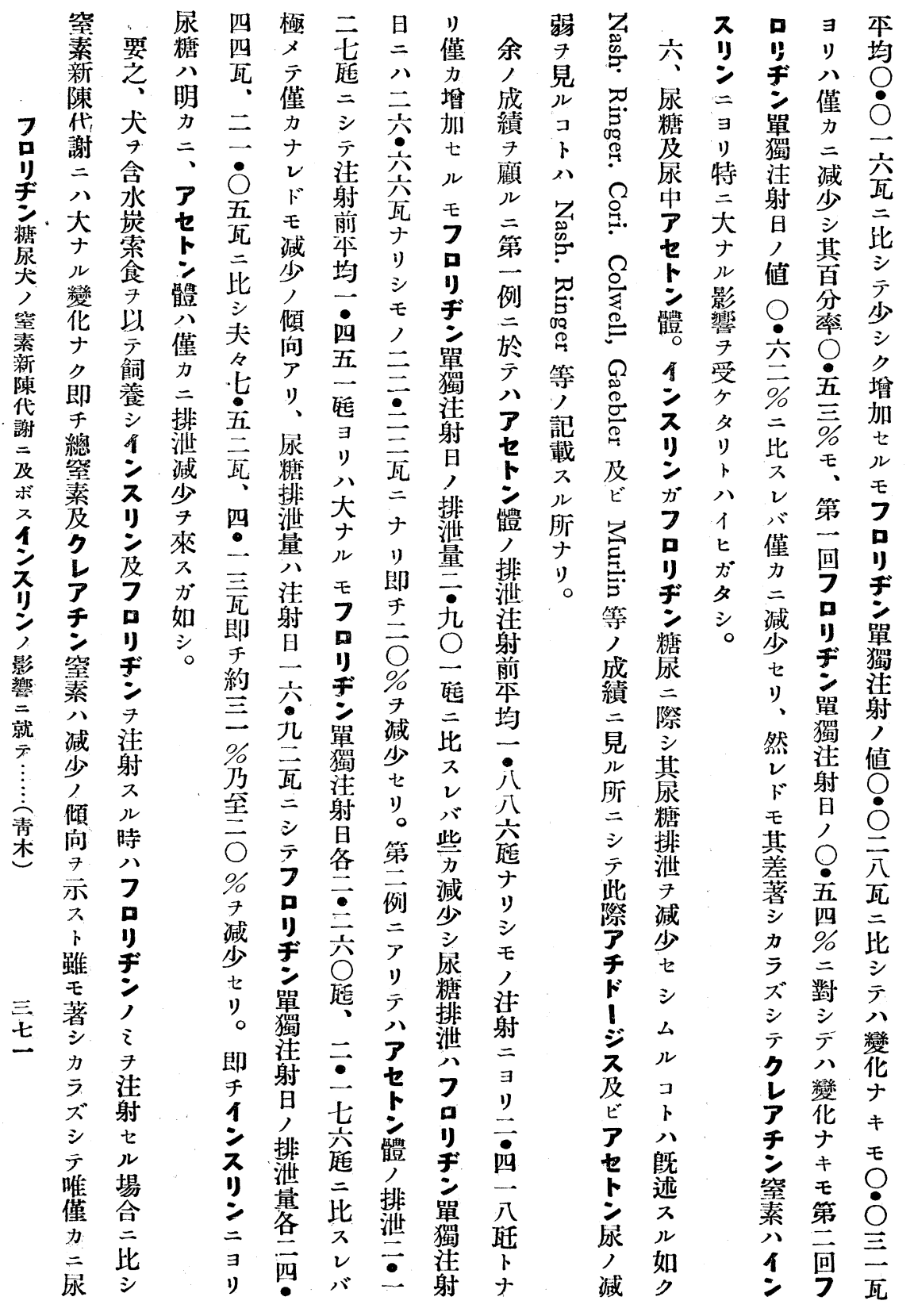




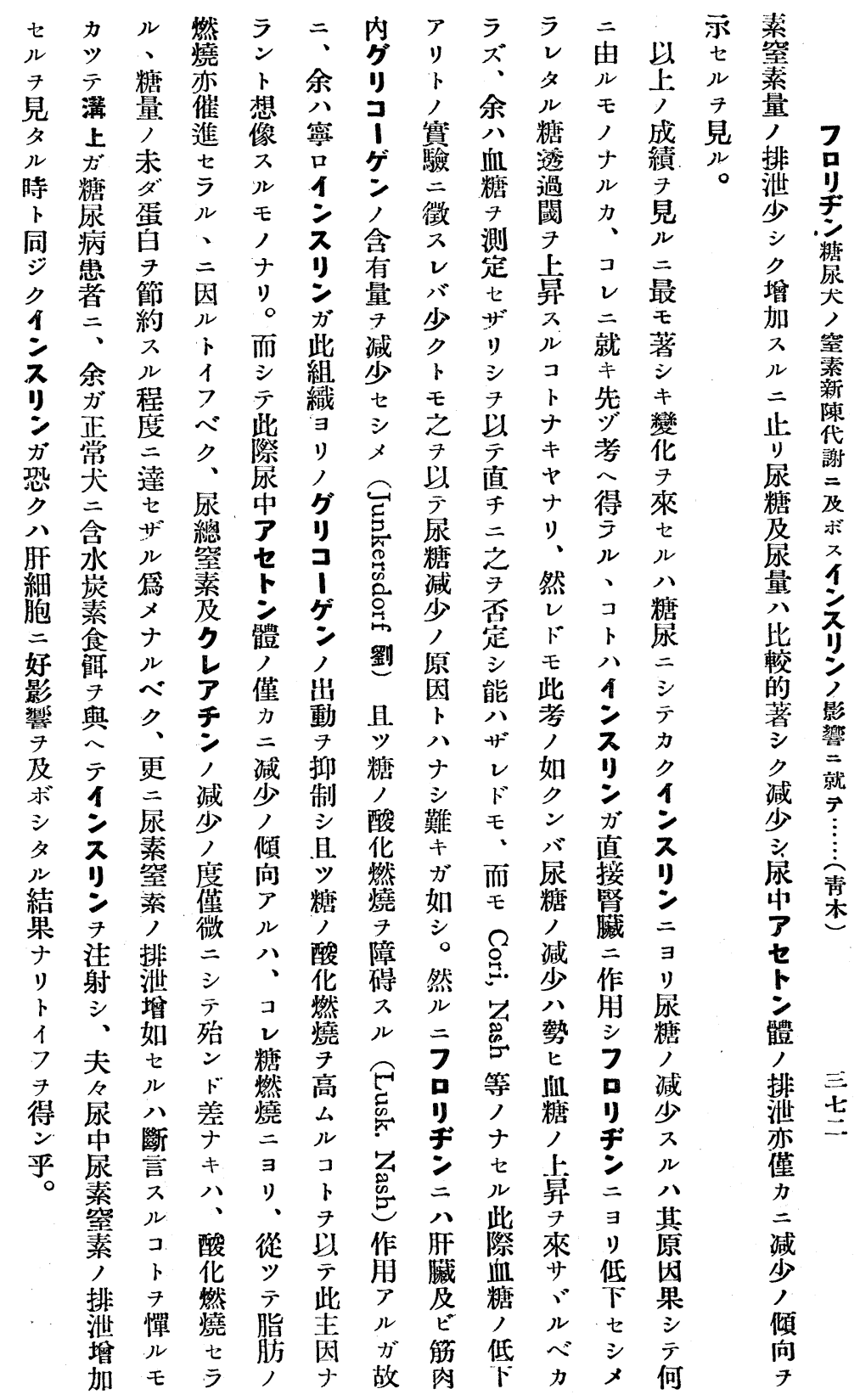




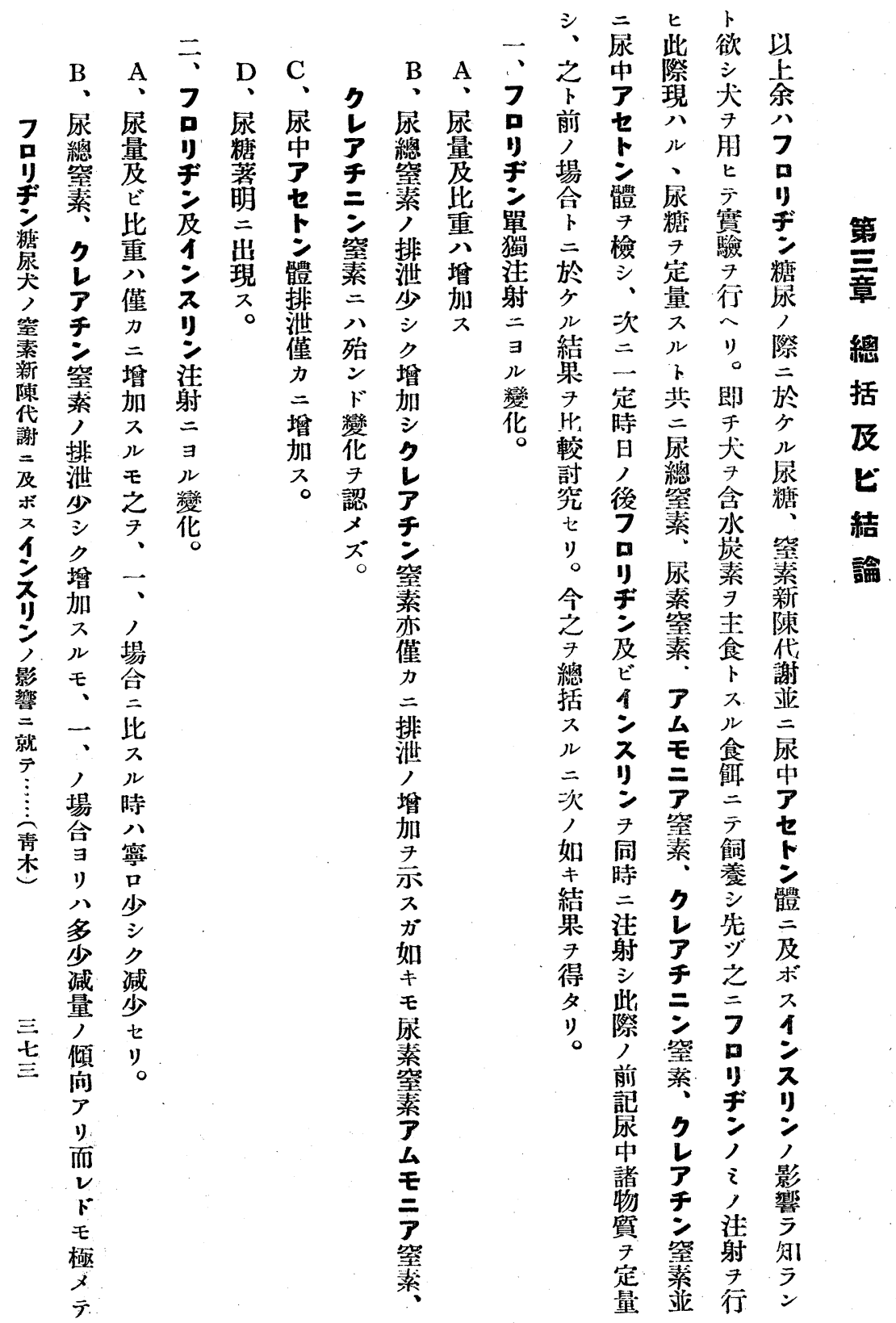




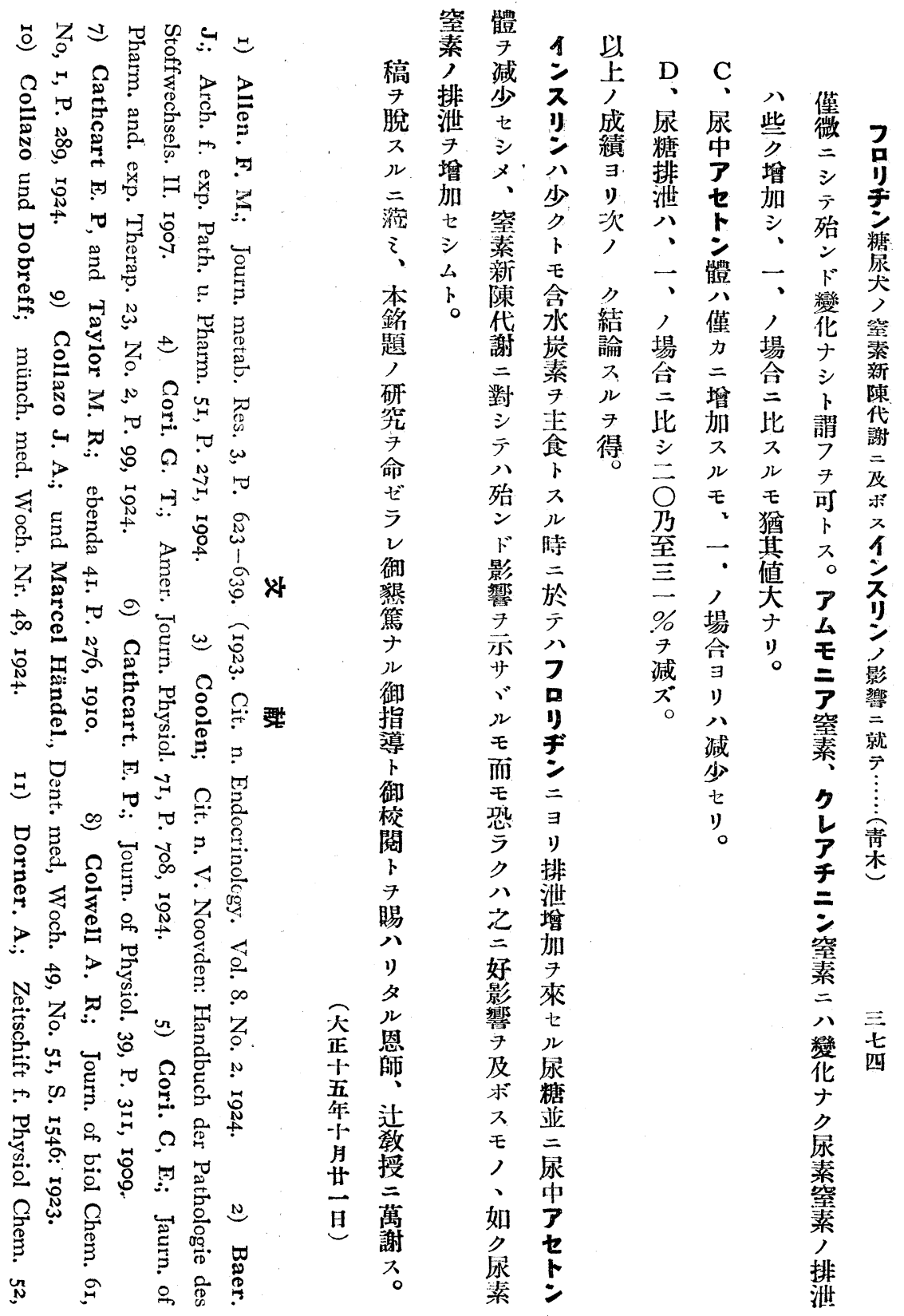




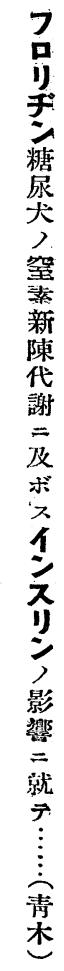

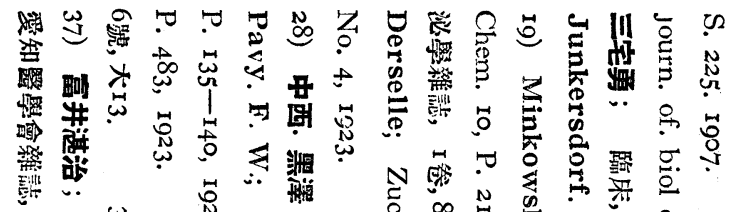

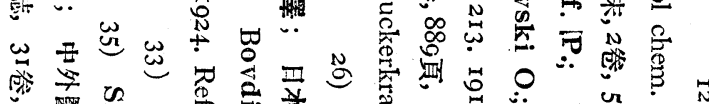

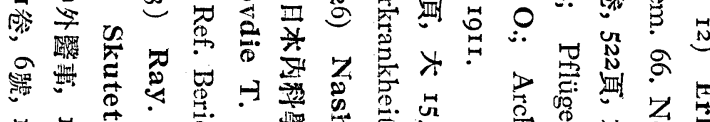

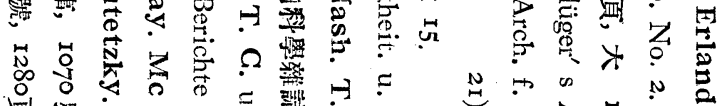

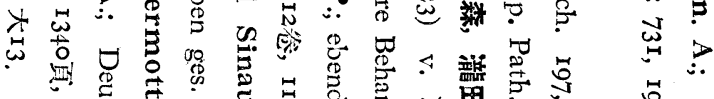

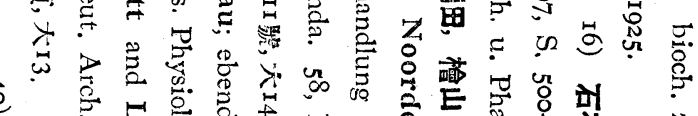

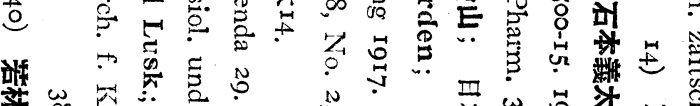

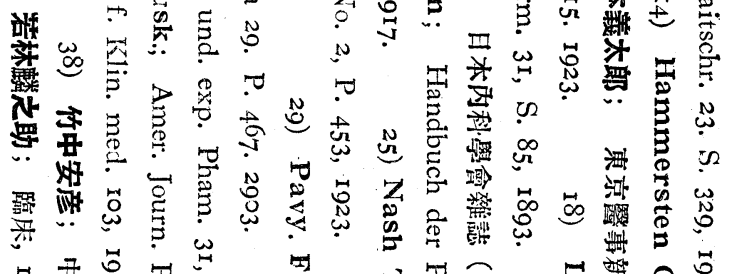

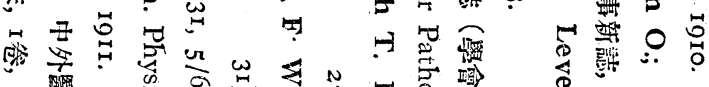

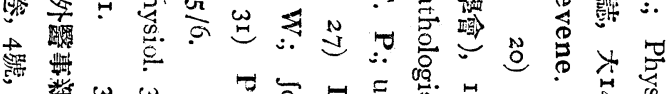

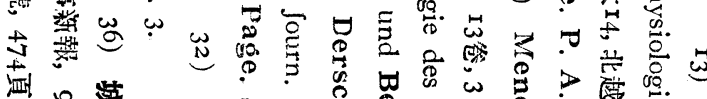

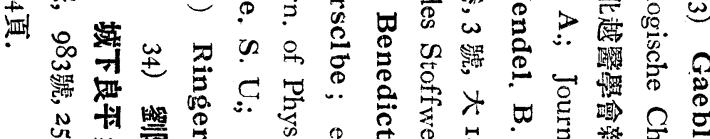

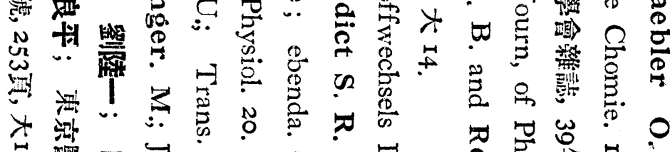

壼

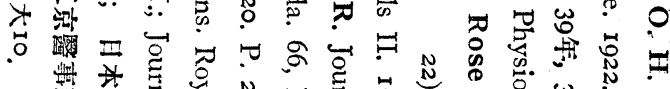

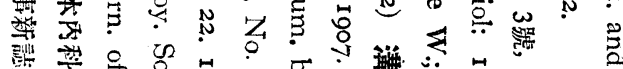

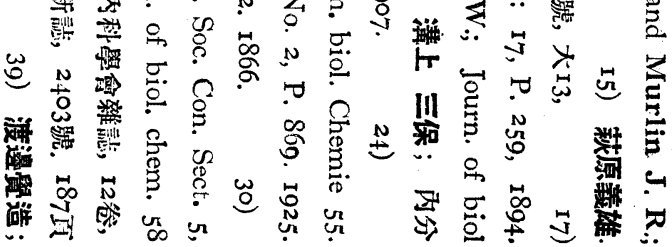




\title{
THE INFLUENCE OF INSULIN UPON THE PROTEIN METABOLISM IN THE PHLORHIZIN \\ GLYCOSURIA.
}

\author{
by
}

Dr. K. Aoki.

(From the First Medical Clinic of the Imperial University of Kyoto. Director: Professor K. Tsuji. M. D.)

In order to ascertain, whether the insulin may influence on the protein metabolism, excretion of sugar and acetonbodies in the phlorhizin diabetes, the present experiments were carried out in two female dogs weighing ro.25 kilograms and 12.50 kilograms. The dog was kept in an ordinary metabolic cage and fed on carbohydrate-rich diets (the mixture of rice 180 gms., lean beaf 75 gms., soy ro gms., which contained carbohydrate 129.83 gms., protein 28.05 gms., fat 4.75 gms. and the mixture of rice 200 gms., lean beaf $95 \mathrm{gms}$., soy ro gms, which contained carbohydrate ${ }_{15} 8.6 \mathrm{r}$ gms, protein $34.96 \mathrm{gms}$. fat 6.00 gms. for each of them.)

The urine was collected and diluted to a constant volume each day.

The ' method employed for estimation were : total nitrogen, Kieldahl; urea, Plimmer-Skelton, ammonia, creatinine and creatin, Folin; aceton and aceto-acetic acid, Messinger-Huppert; and sugar, Pary-KumagawaSudo.

As soon as the animals were in nitrogenous equilibrium, I $\mathrm{gm}$ (for the first $\mathrm{dog}$ ) or $1.2 \mathrm{gm}$ (for the second $\mathrm{dog}$ ) of phlorhizin dissolved in $20 \mathrm{ccm}$ of $\mathrm{r} \%$ sodium carbonate solution was injected subcutaneously, and a few days after again same dosis of phlorhizin with 6 or 7 unite of insulin was administrated subcutaneously.

These dealings were conolusively attended by the following phenomena. 
I) The effect of phlorhizin injection.

a) Increase both in quantity and specific gravity of the urine.

b) Slight increase of total nitrogen and creatin output was found, but no appreciable change of the urea, ammonia and creatinin excretion.

c) Slight increase of the aceton and aceto-acetic acid excretion.

d) Remarkable output of sugar.

II) The effect of phlorhizin and insulin injection.

a) Slight increase in the quantity and specific gravity of the urine, but slight decrease in comparison with those of the former case.

b) No remarkable change of the total nitrogen, ammoniak, creatinine and creatin output, except an increase of the urea excretion.

c) Slight decrease of the aceton and aceto-acetic acid excretion in comparison with those of the former case.

d) Diminution of sugar output, 20 to $3 \mathrm{r} \%$ less than those of the former case.

From above-mentioned results, it may be concluded as follows.

The insulin causes a diminution of the sugar and acetonbodies excretion produced by phlorhizin injection in the carbohydrate-rich diet, but seems to have no remarkable effect upon the protein metabolism. However from the fact that the excretion of urea is increased by insulin injection, it may be suggested that insulin has, if anything, some good effect upon the protein metabolism. (Auther's abstract.)

\section{UEBER DEN EINFLUSS DER SCHILDDRÜSE AUF}

\section{DAS RETIKULO-ENDOTHELIALE SYSTEM.}

\section{Von}

Dr. S. Miyamura u. Dr. G. Ogawa.

(Aus der r. Med. Klinik der Kaiserl. Univers. zu Kyoto.

Direktor: Prof. Dr. K. Tsuji.)

Um den Einfluss der Schilddrüse auf das Blutreinigungsvermögen 